\title{
IMPACT OF INFORMATION QUALITY ON CUSTOMER PERCEIVED VALUE, EXPERIENCE QUALITY, AND CUSTOMER SATISFACTION FROM USING GOFOOD APLICATION
}

\author{
Tundung Subali Patma ${ }^{1 *}$, Nilawati Fienaningsih ${ }^{1}$, Karisma Sri Rahayu ${ }^{1}$ and I Gusti Lanang Suta \\ Artatanaya $^{2}$ \\ ${ }^{1}$ Business Administration, Malang State Polytechnic, 65141, Indonesia \\ ${ }^{2}$ Business Administration, Bali State Polytechnic, 1064, Indonesia
}

\begin{tabular}{|c|c|}
\hline ABSTRACT & ARTICLE INFO \\
\hline 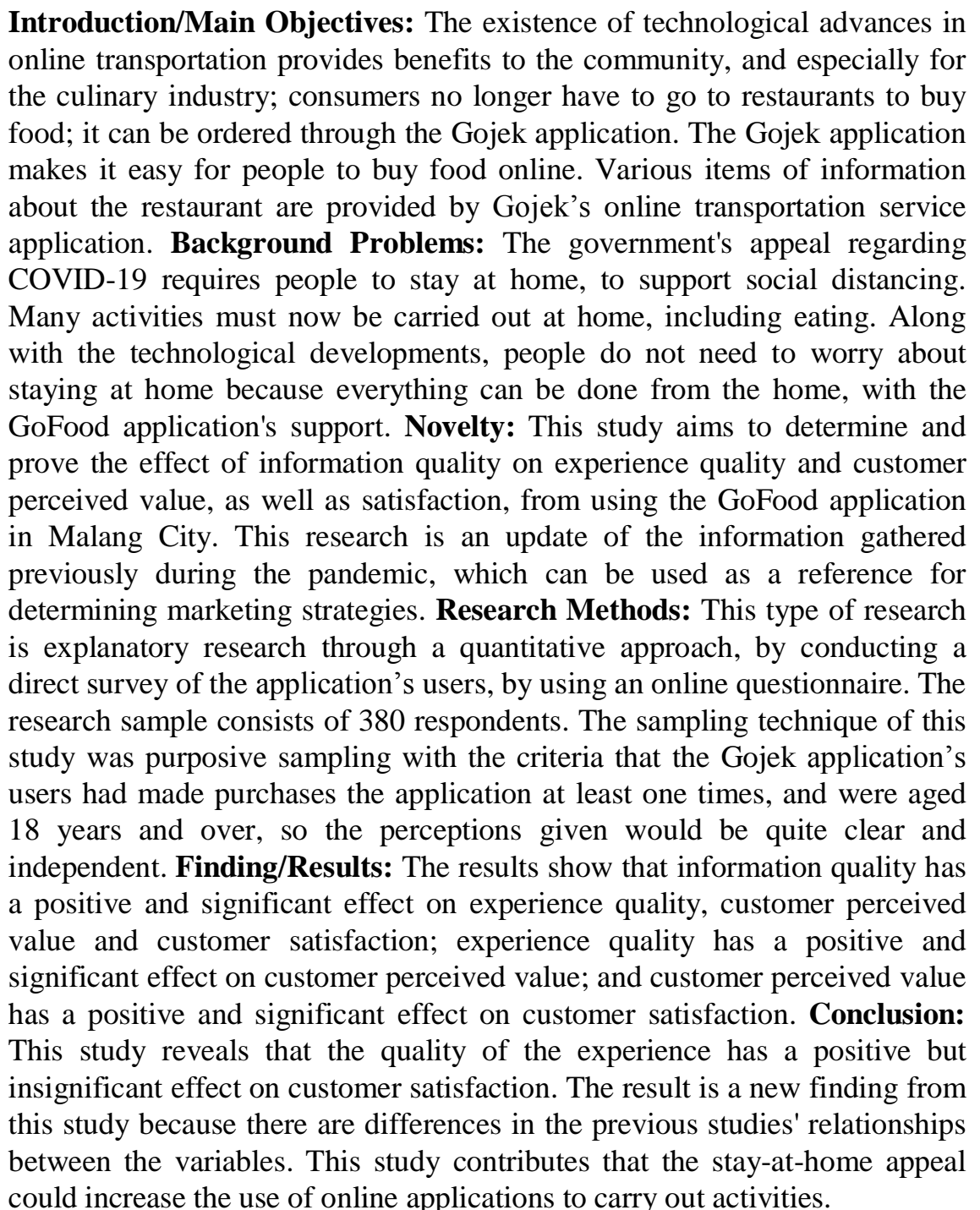 & $\begin{array}{l}\text { Article information: } \\
\text { Received: September 17, } \\
\text { 2020. Received in revised } \\
\text { version: November 4, } \\
\text { 2020. Received in revised } \\
\text { version: December 17, } \\
\text { 2020. Accepted: } \\
\text { December 18, 2020. } \\
\text { Keywords: } \\
\text { information quality, } \\
\text { experience quality, } \\
\text { customer perceive value, } \\
\text { customer satisfaction. }\end{array}$ \\
\hline
\end{tabular}

\footnotetext{
${ }^{1}$ Corresponding Author at Department of Business Adminitration, Malang State Polythecnic, Jalan Soekarno Hatta No. 9, Malang 65141, Indonesia.

E-mail address: tundunu.subali@polinema.ac.id; nilafh@polinema.ac.id; karisma.rahayu@polinema.ac.id; lanangsuta@pnb.ac.id
} 


\section{INTRODUCTION}

Technological advances in recent years, specifically to the internet and e-commerce, have altered the lifestyle of many people. Technology can promote businesses in new ways, which can dramatically improve a company. Also, it can produce new products and services faster than before (Unhelkar, 2006). The emergence of cellular telephone technology transformed the communications industry, with the number of subscriptions reaching 5 billion in 2010. This has led to the continuous development of telephone technology services (Sachdeva, 2010). It can cause the cell phone users to continuously shift from the development of new information technology. One of the information systems that has been developed is online transportation based on applications. It is included in the application of business activities. Online transportation applications need to be further studied to determine a long-term business strategy for them. Information technology (IT) has been utilized in the activities of various sectors for some time now. Almost all fields currently use IT; one of which is the transportation field. The technology behind online transportation services utilizes mobile phone applications, which are now frequently used in daily life.

The appearance of COVID-19 caused an economic breakdown. It has also changed consumer behavior. Studies into these changes have been conducted by the Boston Consulting Group (BCG) which is a global management consulting agency. The results show that, in various countries, there is pessimistic view in consumer sentiment during the pandemic. During this serious health problem, and economic threat, consumer behavior worldwide is changing, particularly regarding shopping behavior. The appearance of COVID-19 caused an economic breakdown. It also changed consumer behavior. Nielsen's study showed the majority of domestic consumers cancelled their trips abroad and reduced the number of times they ate outside the home. They also increased their online shopping activities (Citradi, 2020). During the pandemic and since the implementation of largescale social restrictions (PSBB), there has been no denying that there is a connection between these restrictions and the sustainability of local culinary businesses. Generally, culinary entrepreneurs, including traders and SMEs, have been negatively affected. In contrast, there has been an increase in the number of business transactions for GoFood as an online delivery service (Josina, 2020). This is due to the changes in consumer behavior since the enactment of rules to limit social contact. People have been forced to change their lifestyle and behavior, culinary businesses must also adapt to the new technology to succeed in business. It may prove interesting to study consumer buying behavior further during the COVID-19 pandemic.

Peter \& Olson (2010), defined consumer behavior as a dynamic interaction of aspects of cognition, behavior, and the environment in which humans exchange aspects of their lives. Also, Kotler \& Keller (2009) elucidated consumer behavior as being a study to decide, to purchase, to utilize and to place goods, services, ideas and experiences that are perceived by individuals, groups, and organizations as satisfying their desires and needs. The understanding obtained about consumer behavior needs to be studied further and can be used as a strategy to penetrate the market, after understanding the various market segments. The development of an online transportation service-based mobile phone application system raises many demands that must be met by the service providers, so that consumers who use their services are satisfied. Consumer satisfaction itself will provide many benefits to companies providing online transportation service-based mobile phone applications. 
Al-Dweeri (2017) stated that the information quality in the electronics' field is a factor that has a strong engagement with customer satisfaction. Rai et.al, (2002) argued that the information generated by an information system resulted in more accurate, timely, and reliable information. Further, it increased customer satisfaction. This is interesting and should be studied using the existing technological developments, and information needs to be found to prove its effect on user satisfaction, because quality is the key to a competitive advantage in business (Kusumawati and Rahayu, 2019).

According to DeLone \& McLean (2014), the information quality presented in online transportation service applications can be likened to a two-edged sword. It can attract the customers to use the service, or to ignore it if it does not satisfy them. Therefore, the quality of the information is the main factor to satisfy the customers, especially for satisfying the customers of online transportation services using mobile phone applications (Szymanski \& Hise, 2000). In addition to the information quality, customer satisfaction is also determined based on the quality of the experience. Roy (2018) stated that experience quality had an influence on customer satisfaction for a number of customer behaviors, ranging from new customers to old customers in various service places such as offices, restaurants, and banks. The quality of the information and experience can provide customer satisfaction if it matches the perceived value. This was investigated by Hapsari et.al., (2017) who found the customer value had a direct and significant impact on customer satisfaction. According to the phenomenon and empirical review, this study aims to prove the effect of information quality on the experience quality, customer perceive value, and customer satisfaction with the service offered by
Gojek's food ordering applications. The results of this study contribute to the evaluation of marketing activities during the COVID-19 period. This study adopts the StimulusOrganism-Response (SOR) theory model and consumer behavior theory from Bagoozi (1992) in which the information quality is a stimulus, while the experience quality and customer perceived value are organisms. Customer satisfaction is a form of consumer response. It is hoped that this study's results can contribute to the theory of consumer behavior during the COVID-19 pandemic.

\section{LITERATURE REVIEW}

\section{Information Quality}

McFadden et.al., (1999) defined information as data that were approved to increase an individual's knowledge for using data. The information quality can be generally illustrated by the output of a system, such as the information quality from a system for financial statements (Freeze, 2010). Hsiu \& Gwo (2006) mentioned that information quality determines the output from online communities. Information quality was defined by DeLone \& McLean (2014) as ecommerce content licenses. The content must be personalized, comprehensive, consistent, easy to learn, and safe for potential customers or suppliers undertaking purchases through the internet, and it must respond to the official community. Tam \& Oliveira (2017) conducted research into the quality of information using measurements of usability, understanding, interest, reliability, and completeness. In this study, information quality is how good the information contained in the application (made by the application's founder) is, and how it is provided to the users so that it is easily understood by them. 


\section{Experience Quality}

Experience quality can be defined as the subjective response of consumers who have come into contact with service providers (Lemke, Clark , \& Wilson, 2011). Kao, Huang, and $\mathrm{Wu}$ (2008) conceptualized the experience quality based on four factors, namely immersion, surprise, participation, and fun. Prayag, Hosany, $\&$ Odeh (2011) stated that in defining customer experiences and the influence of consumer reactions, emotions are the most important functions. Roy (2018) defined customer experience as the affective and cognitive aspects resulting from service that can lead to behavioral results, i.e. customer satisfaction. Roy's study was based on consumer surveys conducted in the hospital sector. Further research in the same sector has also been undertaken by Klaus \& Maklan, (2013) and Khan, Garg, \& Rahman, (2015). In this study, experience quality is the experience felt by consumers when using applications.

\section{Customer's Perceived Value}

Even though customer perceived value is comprised of multi-dimensional constructs (Roig, 2006), parts such as service costs are still vital for a customer's evaluation. According to Cronin, Brady, \& Hult, (2000) perceived value is an important predecessor for measuring customer satisfaction. The value from consumers' experiences refers to the perceptions of consumers about the utilization of products or services they have, either directly or indirectly, experienced (Mathwick, Malhotra, \& Rigdon, 2001). Many previous studies, such as those by Jin, Lee, \& Lee, (2013); Suhartanto, Clemes, \& Dean, (2013) and Hapsari, Clemes, \& Dean, (2017) have conducted research into customer perceived value using three dimensions of measurement, namely price, benefit and sacrifice. In this study, customer perceived value is an assessment of the value that is felt, based on the information provided and the experience felt by consumers, compared with the expectations that consumers have regarding the use of the application.

\section{Customer Satisfaction}

According to Choi (2008) even though mCommerce has existed in daily life, the study of customer satisfaction with m-commerce is still limited because of its short history. Homburg \& Giering, (2001) claimed that customer satisfaction exists and creates important problems in marketing because happy consumers can change into dependable consumers who guarantee the profitability of the seller. This is of great importance for the majority of businesses. Satisfaction is an evaluation of how many service providers can meet or exceed consumers' expectations (Levy \& Weitz, 2007). Wu et al., (2016) studied customer satisfaction by using three dimensions for its measurement, i.e. happiness, contentedness, and overall satisfaction. Satisfaction with the use of an application is an output response from the information quality, experience quality and customer perceived value.

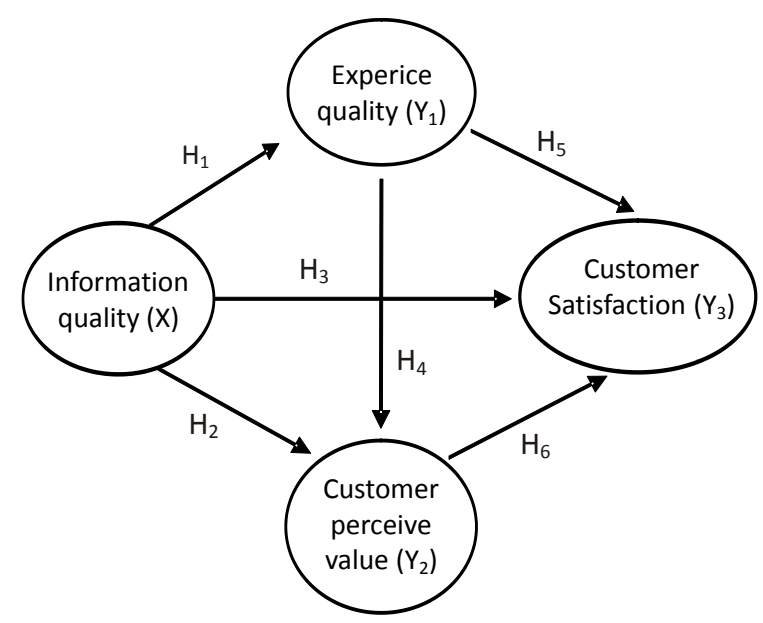

Figure 1. Hyphothesis Model 


\section{METHOD, DATA, AND ANALYSIS}

This type of research is explanatory research with a quantitative approach. This research adopted a quantitative paradigm that was built based on the philosophy of positivism (Echdar, 2017). The population was consumers who use Gojek applications with the age criterion that they must be 18 years and above. This is because age has become a significant concern for social psychologists and marketers (Morris and Venkatesh, 2000). Previous studies also used people in this age range because of their capability to process the information (Sharit and Czaja, 1994). Considering that the use of mobile data services requires some knowledge of their technological and information capabilities; age can be a significant factor influencing consumer data services' adoption behavior. Besides, the other criterion can be the use of the application at least once. This is included as a research criterion because the variables studied are related to experiencing the perceived quality. So, people who already have experience of using the application are expected to be the respondents in this study. The number of samples in this study was determined using Machin's formula. This study collected 380 respondents after performing two iterations of the number of samples. The type of data used in this research are original data collected directly by people filling out questionnaires online.

The data collection method for this research consisted of three stages. Firstly, the creation of an online application which was then distributed by links to respondents that met the criteria. Secondly, the completed data, from a sufficiently sized sample, were collected. Thirdly, the researchers analyzed the data by using the SMartPLS software application. The survey instrument used in this research had been adapted from some of the previous research. For instance, the instrument for the information quality variable was adopted from Tam \& Oliveira, (2017). Experience quality was adopted from Roy, (2018). Customer perceived value was adopted from Hapsari, Clemes, \& Dean, (2017), and customer satisfaction was adopted from Jin, Lee, \& Lee, (2013). The measurement scale used was a Likert scale of 1 to 5 (strongly disagree to strongly agree). This research was conducted over a two month period, from April 2020 until June 2020.

\section{Result and Discussion}

From questionare result The demographics of the sample showed that just over half of the respondents were female, most were aged between 18 to 35 years old with student mayority .All of the respondents placed orders for food via the application at least two times. The details can be seen in Table 1 .

The outer model's evaluation results in this study aimed to determine the validity and reliability of the research's measurement results. The convergent validity results can be seen based on the factor loading value. If the factor loading value $\geq 0.5$, the result is valid (Ghozali \& Latan, 2012). This study found the loading factors for all the variables were above 0.5. Therefore, all the items in this study were valid. Discriminant validity can be evaluated from the results of the outer loading value of each variable. It should be higher than the value of the other variables. The outcomes of the research showed that each research variable had the highest value than another instrument variable about discriminat validity. Composite reliability is evaluated through the value of AVE, which should be more than 0.5 . The composite reliability value and Cronbach's alpha value should both be more than 0.7 , to prove the reliability of the study's construct. In this case, the composite reliability and Cronbach's alpha values were both greater than 0.7 , which meant they were reliable. 
Table 1. Profil Respondent Result

\begin{tabular}{|c|c|c|c|}
\hline No & Information & Amount & $\%$ \\
\hline \multirow[t]{3}{*}{1} & Sex & & \\
\hline & Male & 165 & 43.50 \\
\hline & Female & 215 & 56.50 \\
\hline \multirow[t]{8}{*}{2} & Age (Years) & & \\
\hline & $18-23$ & 194 & 51.00 \\
\hline & $24-29$ & 112 & 29.50 \\
\hline & $30-35$ & 40 & 10.50 \\
\hline & $36-41$ & 18 & 5.00 \\
\hline & $42-47$ & 8 & 2.00 \\
\hline & $48-53$ & 6 & 1.50 \\
\hline & $54-59$ & 2 & 0.50 \\
\hline \multirow[t]{7}{*}{3} & Education & & \\
\hline & Junior High Shcool & 4 & 1.00 \\
\hline & Senior High Shcool & 165 & 43.50 \\
\hline & Diploma & 25 & 6.50 \\
\hline & Barchelor & 171 & 45.00 \\
\hline & Masters & 14 & 3.80 \\
\hline & Doctorate & 1 & 0.20 \\
\hline \multirow[t]{8}{*}{4} & Status/Job & & \\
\hline & Not Working & 42 & 11.00 \\
\hline & Housewife & 5 & 1.50 \\
\hline & Student & 166 & 43.50 \\
\hline & Employee & 129 & 34.00 \\
\hline & $\begin{array}{l}\text { Government } \\
\text { Employee }\end{array}$ & 11 & 2.00 \\
\hline & Professional & 10 & 3.00 \\
\hline & Self Employed & 17 & 5.00 \\
\hline \multirow[t]{3}{*}{6} & Number of times using & application & \\
\hline & $>2$ times & 233 & 61.00 \\
\hline & 2 times & 147 & 39.00 \\
\hline
\end{tabular}

Table 2. R-square result

\begin{tabular}{ll}
\hline Variable & R Square \\
\hline CPV & 0.728 \\
CS & 0.801 \\
EQX & 0.576 \\
\hline
\end{tabular}

PLS test results with structural equations can be seen through the results of testing the inner model, which is used to determine the relationship between one variable and another variable. The evaluation of this model can be seen from the results of the R-square values (R2) for the endogenous variables and the predictive relevance (Q2). The results of the R-square value (R2) from the research showed that the variable of customer perceived value had a great impact, from its value of 0.728 . The customer satisfaction variable also had a great impact, with a value of 0.801 and the experience quality variable had a moderate effect with a value of 0.576. This is in line with the terms stated by Ghozali and Latan (2012). The assessment of the overall goodness of fit was identified from the value of Q2 (predictive relevance). The results of this study indicated a Q2 value of 0.959. It meant that the equation, from the structural basis in this study, had a good goodness of fit.

Table 3. Hypothesis Results

\begin{tabular}{lcccc}
\hline Variable & Original Sample & Standard Deviation & T Statistics & P Values \\
\hline CPV -> CS & 0.202 & 0.053 & 3.845 & 0.000 \\
EQX -> CPV & 0.438 & 0.040 & 10.992 & 0.000 \\
EQX -> CS & 0.082 & 0.043 & 1.918 & 0.056 \\
IQ -> CPV & 0.472 & 0.038 & 12.311 & 0.000 \\
IQ -> CS & 0.657 & 0.044 & 15.022 & 0.000 \\
IQ -> EQX & 0.759 & 0.021 & 36.368 & 0.000 \\
\hline
\end{tabular}


Hypothesis testing in this study was carried out with the bootstrapping method using the SmartPLS 3.0 software application. The result showed that $\mathrm{H} 1$, as the path coefficient of the information quality variable on experience quality was 0.7759 , with a t-test value of 36.368 and a p-value of 0.000 . It meant that the quality of the information had a positive and important effect on the quality of the experience. The $\mathrm{H} 2$ test results showed the value of the path coefficient of the information quality variable to the customers' perceived value was 0.472 , with a t-value of 12.311 and a p-value of 0.000 . It meant that information quality had a positive and significant effect on customer perceived value. The $\mathrm{H} 3$ test results showed the value of the path coefficient for the information quality variables toward customer satisfaction of 0.657 , with a tvalue of 15.022 and a p-value of 0.000 . It meant that the information quality had a positive and significant effect on customer satisfaction. The H4 test results showed the value of the path coefficient of the experience quality variable to the customer perceived value was 0.438 with a tvalue of 10.922 and a p-value of 0.000 . It can be said that experience quality had a positive and significant effect on customer perceived value. The H5 test results showed the value of the path coefficient of the experience quality variable to customer satisfaction was 0.082 with a t-value of 1.918 and a p-value of 0.056 . It meant that the experience quality had a positive but insignificant effect on customer satisfaction. The H6 test results showed the path coefficient value of the customer perceived value variable to customer satisfaction was 0.202 with a t-value of 3.845 and a p-value of 0.000 . It can be said that customer perceived value had a positive and significant effect on customer satisfaction.

Information quality had a positive and significant effect on experience quality, customer perceived value, and customer satisfaction.
This meant that the information provided by the GoFood application can give the impression of a good experience, and the information provided follows the perception of customer perceived value, so that it can create customer satisfaction. Following research by An et al., (2021), useful and complete information can create a memorable experience. Hossain et al., (2020) explained that useful, high-quality information would influence consumer perceptions and create customer satisfaction; which supports the findings of this study. Information quality can contribute to the consumer behavior theory because only a few empirical studies have examined the information quality variables. This study proved that information quality is a stimulus that encourages consumer behavior and a quality experience. Customer perceived value is an organism used as an assessment of what is perceived by consumers, and customer satisfaction is a response to the results of consumer behavior. Experience quality has a positive and significant effect on customer perceived value but was not significant for customer satisfaction. This meant that experience can have an influence on the assessment of consumer expectations and, in line with the research results of Jin, Lee, \& Lee (2013), if the feel of the experience was not memorable, it cannot create a good customer experience. This supports the research of Murphy, Moscardo, Pierre \& Pearce (2011).

On the other hand, experience quality had an indirect effect on customer satisfaction through customer experience. This meant that customer perceived value played an important role in the formation of customer satisfaction, where customer perceived value was more than an assessment of the perceived experience, so that it created customer satisfaction. This agrees with the results found by Kusumawati \& Rahayu (2020). Customer perceived value had a positive 
and significant effect on customer satisfaction; this meant that the consumers' positive values can create customer satisfaction. This study's results mirror the results of previous research conducted by Hapsari, Clemes, \& Dean (2017) and Suhartanto, Clemes, \& Dean (2013).

\section{CONCLUSION AND SUGGESTION}

This research aimed to determine the influence of information quality on experience quality, customer perceived value, and customer satisfaction. The results showed that customer satisfaction can be created based on some stimulus of the information provided by the mobile phone application, so it supports the theory of SOR. Customers are satisfied if the result meets their expectations. In contrast, consumers can have a poor perception of the application. In other words, the application does not match the expectations that the consumers have, so the consumers are not satisfied and may well move to another service. To sum up, customer satisfaction with the online transportation service-based mobile phone applications can be formed based on the information provided by the application. Consumers can experience using the application and meeting their expectations.

According to the results of the hypotheses testing, experience quality with customer satisfaction showed different results from previous studies. The effect of the variable for experience quality on customer satisfaction showed insignificant results. This confirms the attitude theory by Bagozzi (1992). According to Bagozzi (1992), a cognitive attitude from a behavioral action when decision-making can create an affective attitude. So, directions produce a behavioral result. Also, it can be concluded that the cognitive attitude's information quality is determined by the information contained in the application. Affective attitude is the experience quality of the overall experience perceived by consumers for both the products and services provided. Also, affective attitude is comprised of customer perceived value, which is the value expected by the consumers. The outcome of such behavior is customer satisfaction. Customer satisfaction is the satisfaction felt after having experience of the service process. It can be concluded that the information provided by the application is in line with the experience. It means that the consumers perceive that the information in the application meets their expectations. In other words, consumers are satisfied with the information provided and with their experience of using application. In this case, the experience perceived by consumers is directly insignificant with consumer satisfaction. Therefore, consumer satisfaction cannot be formed only from experience, it must be balanced with consumer expectations.

Information quality has a positive and important impact covering experience quality, customer perceived value, and customer satisfaction that were also listed as the outcomes of previous studies undertaken by Tam \& Oliveira, (2017); Roy, (2018); and Jin, Lee, \& Lee, (2013). Another finding of the research is that information quality indirectly has a positive and significant influence on customer satisfaction. It is mediated by experience quality including customer perceived value. This is different from the results of previous studies. It mentioned that experience quality seems not to have a significant direct influence on consumer satisfaction. Experience quality and customer perceived value are proven to strengthen customer satisfaction, based on the information quality given with the application. This study can conclude that during the COVID-19 pandemic, consumers used the Gojek application to order food. Based on the Gojek application's information, it was acceptable and provided an experience for consumers. When using the 
application, the consumers' experience did not provide immediate satisfaction; this can happen because the experience they feel is not what they expected, so that satisfaction is not formed. Likewise, the study's results show that if the consumer's perception is based on their experience, the consumer will feel satisfied.

\section{IMPLICATION/LIMITATION AND SUGGESTIONS}

This research expands the context of information quality in the field of culinary mobile application technology, in that information quality plays an important role in forming customer perceived value and customer satisfaction, based on experience quality. Therefore, it can be used as a determinant of long-term business success. The limitation of this research is the respondent's criteria can describe only during the COVID-19 pandemic. This study only examines the experience of customers who have used and made purchasing decisions with the application at least once. It should also have considered first-time consumers who may make in-app purchase decisions. Future studies are expected to examine first-time consumers and add many other variables that determine long-term business success, such as customer loyalty. Further research can add several other variables that can affect customer loyalty, one of which is trust, and research can be conducted with different objects, such as the Grab mobile application, so that this research's results can be used as a comparison.

\section{REFERENCE}

Al-dweeri, R. M., Obeidat, Z. M., Al-dwiry, M. A., Alshurideh, M. T., \& Alhorani, A. M. (2017). The impact of e-service quality and e-loyalty on online shopping: moderating effect of e-satisfaction and e-trust. International Journal of Marketing Studies,
9(2), 92-103.

https://doi.org/10.5539/ijms.v9n2p92

An, S., Choi, Y., \& Lee, C.-K. (2021). Virtual travel experience and destination marketing: effects of sense and information quality on flow and visit intention. Journal of Destination Marketing \& Management, 19 (November 2020), 100492. https://doi.org/10.1016/j.jdmm.2020.100492

Choi, J. (2008). Customer satisfaction factors of mobile commerce in Korea. Internet Research Vol. 18 No. 3, 313-335.

Citradi, T. (2020, April 14). Not only hitting optimism, Corona also changes consumer behavior. Retrieved from: www.cnbcindonesia.com.

Cronin Jr, J. J., Brady, M. K., \& Hult, G. T. M. (2000). Assessing the effects of quality, value, and customer satisfaction on consumer behavioral intentions in service environments. Journal of retailing, 76(2), 193-218. https://doi.org/10.1016/S00224359(00)00028-2

Delone, W. H., \& Mclean, E. R. (2004). Measuring e-commerce success: Applying the DeLone \& McLean information systems success model. International Journal of electronic commerce, 9(1), 31-47. https://doi.org/10.1080/10864415.2004.110 44317

Echdar, S. (2017). Management and Business Research Methods. Bogor: Ghalia Indonesia.

Ghozali, I., \& Heng, L. (2012). Partial Least Square, Concepts, Techniques, and Applications SMART PLUS 2.0 M3 For Business Research. Semarang: Diponegoro Publisher Agency.

Hapsari, R., Clemes, M., \& Dean, D. (2016). The mediating role of perceived value on the relationship between service quality and customer satisfaction: Evidence from Indonesian airline passengers. Procedia Economics and Finance, 35(12), 388-95. https://doi.org/10.1016/S22125671(16)00048-4 
Homburg, C., \& Giering, A. (2001). Personal characteristics as moderators of the relationship between customer satisfaction and loyalty-an empirical analysis. Psychology \& Marketing, 18(1), 43-66.

Hossain, U., Jerin, I., Al, H., Bakar, A., Hamid, A., Shaharudin, A., \& Latiff, A. (2020). Does quality stimulate customer satisfaction where perceived value mediates and the usage of social media moderates? Heliyon, 6(December), e05710.

https://doi.org/10.1016/j.heliyon.2020.e057 10

Hsiu, F. L., \& Gwo, G. L. (2006). Determinants of success for online communities: an empirical study. Behaviour and Information Technology Vol. 25 No. 6, 479-488.

Jin, N., Lee, S., \& Lee, H. (2013). The effect of experience quality on perceived value, satisfaction, image and behavioral intention of water park patrons: new versus repeat visitors. International Journal of Tourism Research, 17(1), 82-95.

Josina. (2020, May 17). During the Pandemic, GoFood Transactions Increase. Retrieved from detik.com: https://inet.detik.com/cyberlife/d5018169/selama-pandemi-transaksi-gofoodmeningkat

Khan, I., Garg, R. J., \& Rahman, Z. (2015). Customer service experience in hotel operations: an empirical analysis. ProcediaSocial and Behavioral Sciences, 189, 266274.

https://doi.org/10.1016/j.sbspro.2015.03.222

Klaus, P. P., \& Maklan, S. (2013). Towards a better measure of customer experience. International Journal of Market Research, 55(2), 227-246.

https://doi.org/10.2501/IJMR-2013-021

Kotler, P., \& Keller, K. L. (2009). Marketing. Jakarta: Erlangga.

Kusumawati, A., \& Rahayu, K. S. (2019). The role of experience quality and customerperceived value on customer satisfaction and customer loyalty: a case study of indonesian outdoor cafés. International Journal of Innovation, Creativity and Change, 8(9), 143-159.

Kusumawati, A., \& Rahayu, K. S. (2020). The effect of experience quality on customer perceived value and customer satisfaction and its impact on customer loyalty. TQM Journal. https://doi.org/10.1108/TQM-052019-0150

Lemke, F., Clark , M., \& Wilson, H. (2011). Customer experience quality: an exploration in business and consumer contexts using repertory grid technique. Journal of the Academy of Marketing Science 39, 846-869.

Levy, M., \& Weitz, B. A. (2007). Retailing management. Boston: McGraw-Hill/Irwin.

Mathwick, C., Malhotra, N., \& Rigdon, E. (2001). Experiential value: conceptualization, measurement and application in the catalog and internet shopping environment. Journal of Retailing 77, 39-56.

McFadden, F. R., Hoffer, J. A., \& Prescott, M. B. (1999). Modern database management 5th edition. Boston: Addison Wesley

Murphy, L., Moscardo, G., Benckendorff, P., \& Pearce, P. (2011). Evaluating tourist satisfaction with the retail experience in a typical tourist shopping village. Journal of Retailing and Consumer Services, 18(4), 302-310.

https://doi.org/10.1016/j.jretconser.2011.02. 004.

Prayag, G., Hosany, S., \& Odeh, K. (2013). The role of tourists' emotional experiences and satisfaction in understanding behavioral intentions. Journal of Destination Marketing and Management, 2(2), 118-127. https://doi.org/10.1016/j.jdmm.2013.05.001

Rai, A., Sandra, S. L., \& Welker, R. B. (2002). Assessing the validity of is success model: an empirical test and theoretical analysis. Information Systems Research, 13 (1), 5069.

Roy, S. (2018). Effects of customer experience across service types, customer types and time. Journal of Services Marketing, 32(4), 
400-413. https://doi.org/10.1108/JSM-112016-0406

Sachdeva, S. (2010). Mobile commerce: an overview. Seminar Mobile Services, Technische Universitaet Berlin, pp. 1-9.

Suhartanto, D., Clemes, M., \& Dean, D. (2013). analyzing the complex and dynamic nature of brand loyalty in the hotel industry. Tourism Review International Vol.17, 4761.

Szymanski, D. M., \& Hise, R. (2000). Esatisfaction: an initial examination. Journal of Retailing Vol. 76 No. 3, 309-322.

Tam, C., \& Oliveira, T. (2017). Understanding mobile banking individual performance: the
DeLone and McLean model and the moderating effects of individual culture. Internet Research, Vol. 27 Issue: 3.

Unhelkar, B. (2006). Handbook of research in mobile business: technical, methodological, and social perspective, Vol. 1 Ch. 1-30. Pennsylvania: Idea Group Inc.

Wu, H. C., Li, M. Y., \& Li, T. (2018). A study of experiential quality, experiential value, experiential satisfaction, theme park image, and revisit intention. In Journal of Hospitality and Tourism Research (Vol. 42, Issue 1).

https://doi.org/10.1177/1096348014563396 